University of Nebraska - Lincoln

DigitalCommons@University of Nebraska - Lincoln

Agronomy \& Horticulture - Faculty Publications

Agronomy and Horticulture Department

2013

Immunodetection of Triticum mosaic virus by DAS- and DAC-

ELISA using antibodies produced against coat protein expressed

in Escherichia coli: Potential for high-throughput diagnostic

methods

Satyanarayana Tatineni

University of Nebraska-Lincoln, Satyanarayana.Tatineni@ars.usda.gov

Gautam Sarath

United States Department of Agriculture -Agricultural Research Service, Gautam.sarath@ars.usda.gov

Dallas Seifers

Kansas State University, dseifers@ksu.edu

Roy C. French

University of Nebraska-Lincoln, rfrench2@unl.edu

Follow this and additional works at: https://digitalcommons.unl.edu/agronomyfacpub

Part of the Agricultural Science Commons, Agriculture Commons, Agronomy and Crop Sciences Commons, Botany Commons, Horticulture Commons, Other Plant Sciences Commons, and the Plant Biology Commons

Tatineni, Satyanarayana; Sarath, Gautam; Seifers, Dallas; and French, Roy C., "Immunodetection of Triticum mosaic virus by DAS- and DAC-ELISA using antibodies produced against coat protein expressed in Escherichia coli: Potential for high-throughput diagnostic methods" (2013). Agronomy \& Horticulture -Faculty Publications. 680.

https://digitalcommons.unl.edu/agronomyfacpub/680

This Article is brought to you for free and open access by the Agronomy and Horticulture Department at DigitalCommons@University of Nebraska - Lincoln. It has been accepted for inclusion in Agronomy \& Horticulture -Faculty Publications by an authorized administrator of DigitalCommons@University of Nebraska - Lincoln. 


\title{
Immunodetection of Triticum mosaic virus by DAS- and DAC-ELISA using antibodies produced against coat protein expressed in Escherichia coli: Potential for high-throughput diagnostic methods
}

\author{
Satyanarayana Tatineni ${ }^{\mathrm{a}, *}$, Gautam Sarath $^{\mathrm{b}}$, Dallas Seifers ${ }^{\mathrm{c}}$, Roy French ${ }^{\mathrm{a}}$ \\ a USDA-ARS and Department of Plant Pathology, University of Nebraska-Lincoln, Lincoln, NE 68583, USA \\ ${ }^{\mathrm{b}}$ USDA-ARS and Department of Agronomy and Horticulture, University of Nebraska-Lincoln, Lincoln, NE 68583, USA \\ c Kansas State University, Agricultural Research Center-Hays, Hays, KS 67601-9228, USA
}

Article history:

Received 5 November 2012

Received in revised form 25 January 2013

Accepted 30 January 2013

Available online 27 February 2013

\section{Keywords:}

Immunodetection

Recombinant antibodies

DAS-ELISA

Diagnostic method

Field detection

\begin{abstract}
A B S T R A C T
Triticum mosaic virus (TriMV), an economically important virus infecting wheat in the Great Plains region of the USA, is the type species of the Poacevirus genus in the family Potyviridae. Sensitive and high-throughput serology-based detection methods are crucial for the management of TriMV and germplasm screening in wheat breeding programs. In this study, TriMV coat protein (CP) was expressed in Escherichia coli, and polyclonal antibodies were generated against purified soluble native form recombinant $\mathrm{CP}(\mathrm{rCP})$ in rabbits. Specificity and sensitivity of resulting antibodies were tested in Western immuno-blot and enzyme-linked immunosorbent assays (ELISA). In direct antigen coating (DAC)-ELISA, antibodies reacted specifically, beyond 1:20,000 dilution with TriMV in crude sap, but not with healthy extracts, and antiserum at a 1:10,000 dilution detected TriMV in crude sap up to 1:4860 dilution. Notably, rabbit anti-TriMV IgG and anti-TriMV IgG-alkaline phosphatase conjugate reacted positively with native virions in crude sap in a double antibody sandwich-ELISA, suggesting that these antibodies can be used as coating antibodies which is crucial for any 'sandwich' type of assays. Finally, the recombinant antibodies reacted positively in ELISA with representative TriMV isolates collected from fields, suggesting that antibodies generated against rCP can be used for sensitive, large-scale, and broad-spectrum detection of TriMV.
\end{abstract}

Published by Elsevier B.V.

\section{Introduction}

Management of viral diseases include eradication of virus source by rouging of infected plants, cultural practices such as minimizing the virus reservoir hosts and insect vectors, and virus resistant transgenic plants (Hull, 2002). Although transgenic plants would provide significant resistance to viral diseases (Prins et al., 2008), the use of genetically modified plants is not acceptable to a broad range of consumers (Fuchs and Gonsalves, 2007). The commonly practiced control measures for viral diseases are cultural practices (Jones, 2006). Sensitive, inexpensive, and high-throughput detection methods can play an important role in the management of viral diseases through cultural practices. Nucleic acid-based polymerase chain reaction (PCR) methods are available for many plant viruses, but this method has limitations in terms of cost per reaction and processing a large number of samples. Enzyme-linked immunosorbent assay (ELISA)-based

\footnotetext{
* Corresponding author. Tel.: +1 402472 2710; fax: +1 4024724020

E-mail address: satya.tatineni@ars.usda.gov (S. Tatineni).
}

diagnostic methods are relatively inexpensive and can be used for high-throughput detection of samples (Clark and Adams, 1977).

Triticum mosaic virus (TriMV) has been reported recently from the Great Plains region of the USA (Seifers et al., 2008). TriMV is the type species of the genus Poacevirus in the family Potyviridae (http://ictvonline.org/virusTaxonomy.asp?version=2011; Adams et al., 2011; Fellers et al., 2009; Tatineni et al., 2009). TriMV possesses a 10,266 nucleotide long, single-stranded, positivesense genomic RNA with genomic organization similar to that of other monopartite potyvirid species (Tatineni et al., 2009). TriMV differs from other potyvirid species, with a substantially divergent polyprotein and an unusually long 5'-nontranslated region (Tatineni et al., 2009). Recently, the P1 protein of TriMV was reported as a suppressor of RNA silencing and a pathogenicity determinant (Tatineni et al., 2012). TriMV is transmitted by the eriophyid mite Aceria tosichella Keifer (Seifers et al., 2009), which is also a vector for Wheat streak mosaic virus (WSMV), another economically important virus in the Great Plains region. Since TriMV and WSMV are transmitted by a common vector, double infections in wheat by these two viruses have been reported in growers' fields (Byamukama et al., 2013; Burrows et al., 2009). In co-infected 
wheat plants, WSMV and TriMV interact synergistically with each other, causing increased virus titers and severe effects on growth and yield determinants (Byamukama et al., 2012; Tatineni et al., 2010). Both TriMV and WSMV induce indistinguishable chlorotic streaks, mosaic, and mottling symptoms on wheat, and identification of these two viruses based on symptomatology is difficult. Efficient diagnostic methods are crucial for the management of viral diseases and for germplasm screening in breeding programs. Hence, sensitive and specific diagnostic methods are needed for large-scale detection of TriMV.

Antibodies produced against purified virions have widely been used for diagnosis of plant viral diseases (Hull, 2002). However, some viruses are difficult to purify to obtain sufficient quantities of virions without host protein contamination and most of the potyvirid species are no exception to this. Moreover, a large greenhouse space and expensive equipment are required for purification of viruses. To overcome these limitations, monoclonal antibodies have been produced for several plant viruses (Sander and Dietzgen, 1984). Even though monoclonal antibodies have been used successfully for viral diagnosis, monoclonal antibodies usually lack the broad-spectrum specificity required for detecting related strains/isolates of a virus (Dekker et al., 1987). Alternatively, viral structural proteins expressed in bacteria have been used as antigens to produce polyclonal antibodies for several plant viruses (e.g. Abou-Jawdah et al., 2004; Durrin et al., 2010; Gulati-Sakhuja et al., 2009; Khatabi et al., 2012). A major concern with antibodies produced against recombinant proteins is that these antibodies mainly react with denatured proteins in Western immuno-blots and direct antigen coating (DAC)-ELISA, but generally not with native virions in double antibody sandwich (DAS)-ELISA, a widely used method as a diagnostic tool by researchers and biotechnology companies.

Recently, polyclonal antibodies were produced against partially purified virions of the 06-123 isolate of TriMV (Seifers et al., 2008). These antibodies reacted weakly with TriMV-infected crude sap in DAC-ELISA with OD $_{405}$ values of 0.2-0.6 (Seifers et al., 2008). Hence, there is a need to produce antibodies with high specific activity and sensitivity to develop unambiguous high-throughput detection methods for TriMV. In this report, polyclonal antibodies were produced against TriMV CP expressed in bacteria, and these antibodies reacted specifically and sensitively with TriMV in crude sap, but not with WSMV or healthy extracts in DAC- and DAS-ELISA. Additionally, the recombinant antibodies detected representative TriMV isolates collected from the Great Plains region, suggesting that these antibodies can be used for large-scale and broad-spectrum detection of TriMV.

\section{Materials and methods}

\subsection{Virus maintenance}

Wheat seedlings (cv. Tomahawk) at the single-leaf stage were mechanically inoculated with crude sap extracted from TriMV (isolate Nebraska)-infected tissue as described in Tatineni et al. (2009). For long-term storage, TriMV-infected wheat leaves collected at 14 days post inoculation were stored at $4{ }^{\circ} \mathrm{C}$ under anhydrous calcium sulfate. WSMV isolate Sidney 81 was maintained in wheat by inoculating wheat seedlings (cv. Tomahawk) at the single-leaf stage with in vitro transcripts of pSP6-WSMV as described in Choi et al. (1999).

\subsection{Cloning of TriMV CP cistron into pET-30a (+)}

Synthesis of first-strand cDNA, followed by polymerase chain reaction (PCR) of $\mathrm{CP}$ cistron, and cloning into pET-30a (+) (EMD Millipore, Darmstadt, Germany) were performed using standard molecular biology methods as described in Sambrook and Russell (2001).

Viral RNA extracted from partially purified virions (Tatineni et al., 2009) was used to generate first-strand cDNA using an oligonucleotide $\operatorname{Tr}-32$ (nucleotides complementary to 10,26610,246, followed by 105 thymidine residues and Not I and Sma I restriction sites). The $\mathrm{CP}$ cistron was amplified using cDNA generated with $\mathrm{Tr}-32$ oligonucleotide as a template with a forward primer Tr-99 (nucleotides corresponding to 9195-9223 with an Ncol restriction site) and a reverse primer Tr-100 (nucleotides complementary to $10,078-10,049$ with an $X$ hol restriction site). The PCR program consisted of a single cycle at $94^{\circ} \mathrm{C}$ for $2 \mathrm{~min}, 35$ cycles at $94^{\circ} \mathrm{C}$ for $20 \mathrm{~s}, 54{ }^{\circ} \mathrm{C}$ for $20 \mathrm{~s}$, and $72^{\circ} \mathrm{C}$ for $60 \mathrm{~s}$, followed by a single cycle at $72^{\circ} \mathrm{C}$ for $5 \mathrm{~min}$. The RT-PCR product of CP was digested with NcoI and XhoI restriction enzymes (New England BioLabs) and ligated inframe into similarly digested pET-30a $(+)$. The authenticity of TriMV CP in pET-30a (+) was verified by nucleotide sequencing at the University of Florida ICBR Core DNA Sequencing Facility using an Applied Biosystems 3730 model sequencer.

\subsection{Expression of TriMV CP in E. coli}

The pET-30a (+) containing TriMV CP was transformed into E. coli strain Rosetta (EMD Millipore) and a single isolated colony was inoculated to $40 \mathrm{ml}$ Luria-Bertani media plus $50 \mu \mathrm{g} / \mathrm{ml}$ kanamycin (LB-kan). The culture was incubated overnight at $30^{\circ} \mathrm{C}$. Two hundred milliliters of LB-kan media was inoculated with overnight grown culture at a 1:200 dilution and incubated at $37^{\circ} \mathrm{C}$. The culture was transferred to $18^{\circ} \mathrm{C}$ for $30 \mathrm{~min}$ when $\mathrm{OD}_{600}$ of the culture reached 0.4-0.6. Expression of TriMV CP from E. coli was induced with the addition of IPTG to $1 \mathrm{mM}$, and further incubated overnight at $18^{\circ} \mathrm{C}$. The overnight grown culture was centrifuged at $6000 \times \mathrm{g}$ for $10 \mathrm{~min}$ and the pellet was stored at $-20^{\circ} \mathrm{C}$. The levels of $\mathrm{CP}$ expression before and after addition of IPTG was examined by electrophoresis of total proteins from $E$. coli culture equivalent to 0.15 OD at $600 \mathrm{~nm}$ using SDS polyacrylamide gels (SDS-PAGE).

\subsection{Purification of bacterially expressed $C P$}

A frozen $E$. coli pellet was suspended in cold $10 \mathrm{ml}$ extraction buffer $(9.6 \mathrm{ml}$ of $20 \mathrm{mM}$ sodium phosphate buffer, $\mathrm{pH} 7.4$, $0.5 \mathrm{M}$ sodium chloride, and $20 \mathrm{mM}$ imidazole; and $0.4 \mathrm{ml}$ of $20 \mathrm{mM}$ sodium phosphate buffer, $\mathrm{pH} 7.4,0.5 \mathrm{M}$ sodium chloride, and $0.5 \mathrm{M}$ imidazole plus $1.0 \mathrm{mg}$ lysozyme) by pipetting up and down. The resuspended pellet was sonicated for $5 \mathrm{~min}$ with $10 \mathrm{~s}$ on and $20 \mathrm{~s}$ off cycles at $20 \%$ amplitude, followed by 5 min sonication with $10 \mathrm{~s}$ on and 20 s off cycles at $22 \%$ amplitude. The sonicated $E$. coli lysate was centrifuged at $14,000 \times g$ for $5 \mathrm{~min}$ at $4{ }^{\circ} \mathrm{C}$. The supernatant was injected into the AKTA ${ }^{\mathrm{TM}}$ protein purifier (Amersham Biosciences) and passed over a chelating resin charged with nickel $\left(\mathrm{Ni}^{2+}\right)$. After washing non-bound proteins, bound proteins were eluted with a linear gradient of loading buffer containing imidazole $(20-500 \mathrm{mM})$; fractions with the most protein were collected and dialyzed against phosphate-buffered saline (PBS) for overnight at $4{ }^{\circ}$ C. Purity of eluted protein was verified by SDS-PAGE and was estimated to be $>95 \%$.

\subsection{Production of polyclonal antibodies against $\mathrm{CP}$ expressed in bacteria in rabbits}

Polyclonal antibodies against TriMV CP expressed in bacteria were produced in two rabbits by Cocalico Biologicals, Inc. (Reamstown, PA). First, each rabbit was injected with $100 \mu \mathrm{g}$ of column purified bacterially expressed CP mixed with Freund's complete adjuvant $(1: 1, v / v)$. Subsequently, each rabbit was administered three additional doses of $50 \mu \mathrm{g}$ of $\mathrm{CP}$ per injection mixed with equal 
volumes of Freund's incomplete adjuvant at 14, 21 and 49-day intervals. First test bleeds were collected 35 days after the initial immunization. Starting one week after the final immunization, serum was collected four times at 14-day intervals.

\subsection{Rabbit anti-TriMV IgG purification and conjugation with alkaline phosphatase}

Rabbit anti-TriMV IgG was isolated from crude rabbit antiserum produced against $\mathrm{CP}$ expressed in bacteria using a protein A antibody purification kit (Sigma-Aldrich, St. Louis, MO) essentially as described by the manufacturer. Alkaline phosphatase (ALP; Sigma-Aldrich) was conjugated to anti-TriMV IgG using glutaraldehyde as described (Harlow and Lane, 1988). Rabbit anti-TriMV IgG and ALP were mixed at a $1: 2$ ratio and dialyzed against PBS for $4-5 \mathrm{~h}$ with at least two changes at $4{ }^{\circ} \mathrm{C}$, followed by dialysis against PBS in the presence of $0.06 \%$ glutaraldehyde (Sigma-Aldrich) at room temperature for $4 \mathrm{~h}$. Finally, Rabbit anti-TriMV IgG-ALP mixture was dialyzed against PBS containing $0.02 \%$ sodium azide for overnight at $4{ }^{\circ} \mathrm{C}$ with at least two changes of PBS.

\subsection{ELISA procedures}

The titer of polyclonal antibodies produced against rCP in different rabbit bleeds was evaluated by DAC-ELISA as described (Hobbs et al., 1987). Briefly, ELISA plates were coated (100 $\mu \mathrm{l}$ per well) with crude extracts of TriMV- and WSMV-infected and healthy wheat leaves at a 1:20 dilution $(\mathrm{w} / \mathrm{v})$ in $0.05 \mathrm{M}$ carbonate buffer, pH 9.6 (Clark and Adams, 1977). ELISA plates were incubated at $37^{\circ} \mathrm{C}$ for $1 \mathrm{~h}$, followed by three washings at $3 \mathrm{~min}$ intervals with PBS plus 0.05\% (v/v) Tween-20 (PBS-T). Antiserum diluted in antibody buffer [PBS-T plus $2 \%$ polyvinylpyrrolidone (MP Biomedicals, Santa Ana, CA) and $0.2 \%$ albumin chicken egg white (MP Biomedicals)] was added, and ELISA plates were incubated at $37^{\circ} \mathrm{C}$ for $1 \mathrm{~h}$. After washing ELISA plates with PBS-T, goat antirabbit IgG-alkaline phosphatase (ALP) conjugate (Sigma-Aldrich) in antibody buffer was added at a 1:2000 dilution and incubated for $1 \mathrm{~h}$ at $37^{\circ} \mathrm{C}$. Finally, ELISA plates were washed with PBS-T and p-nitrophenyl phosphate (Sigma-Aldrich, $1 \mathrm{mg} / \mathrm{ml}$ ) in $0.1 \mathrm{M}$ diethanolamine buffer, $\mathrm{pH} 9.8$ was added as a substrate. ELISA plates were read at 30,45 , and $60 \mathrm{~min}$ following the addition of substrate for the development of yellow color at $\mathrm{OD}_{405}$ in a SpectraMax plate reader (Molecular Devices, Sunnyvale, CA). A sample was considered positive if OD value was at least three times higher than those of negative controls (WSMV-infected and healthy extracts).

DAS-ELISA was performed essentially as described in Clark and Adams (1977). Briefly, ELISA plates were coated with rabbit antiTriMV IgG in $0.05 \mathrm{M}$ carbonate buffer, $\mathrm{pH} 9.6$ and incubated at $4{ }^{\circ} \mathrm{C}$ for overnight or at $37^{\circ} \mathrm{C}$ for $1 \mathrm{~h}$. ELISA plates were washed with PBS$\mathrm{T}$, followed by the addition of crude sap extracted in antibody buffer, and incubated at $37^{\circ} \mathrm{C}$ for $1 \mathrm{~h}$. Rabbit anti-TriMV IgG-ALP conjugate in antibody buffer was added to ELISA plates after washing with PBS-T. After $1 \mathrm{~h}$ incubation at $37^{\circ} \mathrm{C}$, ELISA plates were washed with PBS-T and p-nitrophenyl phosphate substrate $(1 \mathrm{mg} / \mathrm{ml})$ in $0.1 \mathrm{M}$ diethanolamine buffer, $\mathrm{pH} 9.8$ was added as a substrate, and plates were read at $\mathrm{OD}_{405}$ for the development of yellow color due to hydrolysis of substrate at 45,60 , and $90 \mathrm{~min}$ after the addition of substrate using a SpectraMax plate reader.

\subsection{SDS-PAGE and Western blot analysis}

Total soluble proteins from TriMV- and WSMV-infected and healthy wheat leaves were extracted as described (Tatineni et al., 2011). Bacterial proteins and total soluble-proteins from wheat leaves were separated on 4-20\% gradient Tris-glycine-SDS-PAGE gels (Invitrogen, Carlsbad, CA), followed by Coomassie Brilliant Blue
Table 1

Triticum mosaic virus isolates used to evaluate polyclonal antibodies produced against coat protein expressed in bacteria by enzyme-linked immunosorbent assay.

\begin{tabular}{llll}
\hline Isolate $^{\mathrm{a}}$ & State & Date collected & Host \\
\hline 06-123 & Kansas & $04 / 25 / 2006$ & KS06HW79 wheat \\
K10-7407 & Kansas & $11 / 24 / 2010$ & Volunteer wheat \\
K11-80 & Kansas & $04 / 25 / 2011$ & Unknown wheat cultivar \\
C10-43 & Colorado & $04 / 29 / 2010$ & 'Armour' wheat \\
C10-1435 & Colorado & $05 / 27 / 2010$ & 'Ripper' wheat \\
C10-1290 & Colorado & $05 / 27 / 2010$ & 'Ripper' wheat \\
N10-3323 & Nebraska & $05 / 27 / 2010$ & Unknown wheat cultivar \\
N10-4930 & Nebraska & $06 / 03 / 2010$ & Unknown wheat cultivar \\
N10-5071 & Nebraska & $06 / 02 / 2010$ & Unknown wheat cultivar \\
S10-2889 & South Dakota & $07 / 09 / 2010$ & Unknown wheat cultivar \\
\hline
\end{tabular}

a The K, C, N, and S prefixes indicate Kansas, Colorado, Nebraska, and South Dakota, respectively. The numbers 06,10 , and 11 indicated the years 2006, 2010, and 2011, respectively. The numbers following the dashes are sample numbers.

R-250 staining or Western blot analysis. Proteins from SDS-PAGE gels were transferred to PVDF membranes using iBlot dry blotting system (Invitrogen), followed by immunoblotting as described in Tatineni et al. (2011), except that the images of immuno-reactive protein bands were captured using the Molecular Imager ChemiDoc XRS+ with Image Lab Software system (Bio-Rad).

\subsection{Field collected TriMV isolates}

Ten TriMV isolates collected from Kansas, Colorado, Nebraska, and South Dakota (Table 1) were mechanically inoculated to wheat cv. Tomahawk with crude sap at 1:10 dilution (w/v). The inoculated plants were held in a growth chamber (Percival Model PGC-15WC) at $22^{\circ} \mathrm{C}$ with a $12 \mathrm{~h}$ photoperiod of fluorescent light $\left(250 \mu \mathrm{Es}^{-1} \mathrm{~m}^{-2}\right)$ for 14 days and then the tissue was harvested to use as an antigen to evaluate the TriMV antibodies against $\mathrm{rCP}$ in ELISA.

\section{Results}

\subsection{Molecular cloning and expression of TriMV CP in E. coli}

PCR product spanning the CP cistron of TriMV, 885 base pairs encoding 294 amino acids, was cloned in the pET-30a (+) vector downstream of the His-tag, S-Tag and enterokinase sequences. The $\mathrm{CP}$ of TriMV was expressed in E. coli strain Rosetta cells in the presence of $1 \mathrm{mM}$ IPTG at $18^{\circ} \mathrm{C}$ overnight. SDS-PAGE analysis of total proteins from IPTG-induced $E$. coli cells revealed that the $\mathrm{CP}$ was expressed with an estimated molecular weight of $45.0 \mathrm{kDa}$ (Fig. 1A, lane 4), which was approximately similar to that of SDS-PAGE estimated $37.0 \mathrm{kDa}$ of TriMV CP (Seifers et al., 2008) plus $8.0 \mathrm{kDa}$ of His-tag, S-Tag and enterokinase, mostly as a soluble form. In contrast, expression of $45.0 \mathrm{kDa}$ protein was absent in E. coli cells collected prior to the addition of IPTG (Fig. 1A, lane 3). As a control, E. coli cells transformed with the empty vector [pET-30a (+)] did not induce expression of similar-sized protein as observed with pET-30a (+) with TriMV CP (Fig. 1A, compare lanes 1 and 2 with lane 4).

His-tagged $\mathrm{CP}$ free from detectable levels of bacterial proteins was obtained as a soluble native form by passing sonicated E. coli lysate twice through the AKTA ${ }^{\mathrm{TM}}$ protein purification system (Fig. 1A, lanes 5 and 6 ). His-tagged CP expressed in bacteria was used to produce polyclonal antibodies in two rabbits to exclude the possibility of differential immune response between the rabbits.

\subsection{Specificity of antibodies generated against rCP}

The specificity and sensitivity of rabbit antibodies produced against $\mathrm{CP}$ expressed in bacteria was evaluated by Western 
A

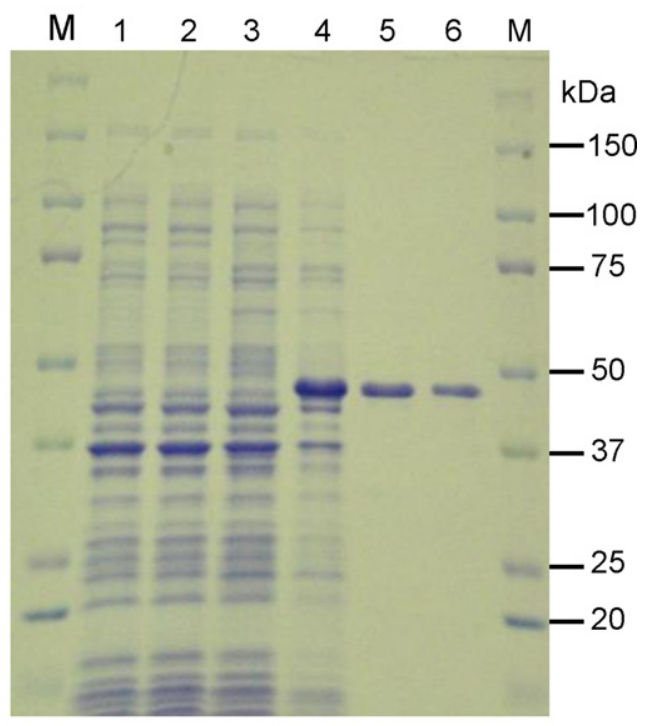

B

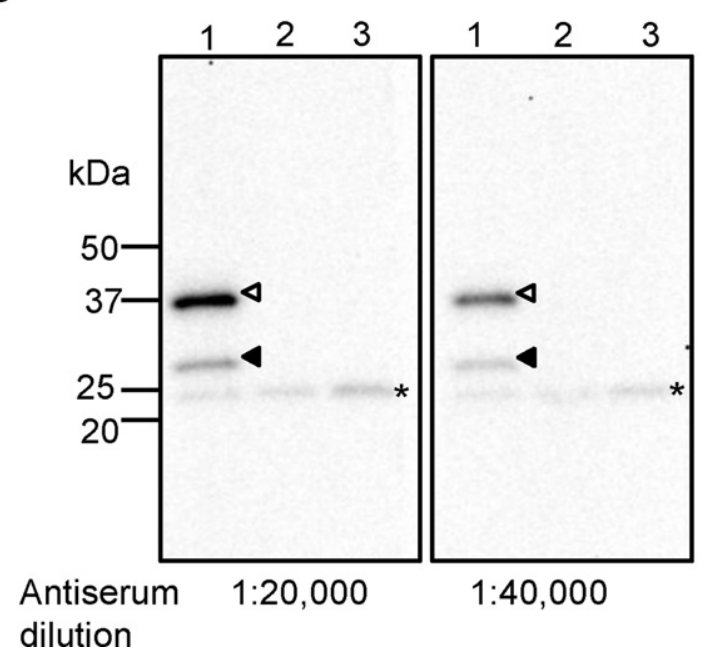

Fig. 1. (A) Sodium dodecyl sulfate-polyacrylamide gel electrophoresis analysis of total proteins of E. coli transformed with the empty vector [pET30a (+)] (lanes 1 and 2) and pET30a (+) with Triticum mosaic virus (TriMV) coat protein (CP) sequence (lanes 3 and 4). E. coli cells were harvested at $0 \mathrm{~h}$ (lanes 1 and 3 ) and overnight (lanes 2 and 4) following the addition of IPTG. Lanes 5 and 6: $10 \mu \mathrm{l}$ and $5 \mu \mathrm{l}$ of Histagged TriMV CP purified through the $\mathrm{AKTA}^{\mathrm{TM}}$ protein purifier. Lanes M: protein markers. (B) Western blot analysis of total proteins from TriMV- (lane 1) and Wheat streak mosaic virus- (lane 2) infected, and healthy (lane 3 ) leaves using antibodies raised against recombinant coat protein (rCP) of TriMV. Ten $\mu$ l of 1:10 diluted total proteins were loaded per well, and dilution of primary antibodies raised against rCP are indicated at the bottom of blots. Goat anti-rabbit IgG conjugated to HRP was used at a 1:50,000 dilution. A weakly reacting healthy protein of $\sim 24 \mathrm{kDa}$ is indicated with asterisks. A $37 \mathrm{kDa}$ full-length and a $28 \mathrm{kDa}$ truncated $\mathrm{CP}$ of TriMV reacting with antibodies are indicated with solid and hollow triangles, respectively.

immuno-blot and ELISA. Antiserum from the 1 st bleed was used to evaluate the specificity of antibodies to TriMV in Western immunoblots. Antiserum diluted $1: 20,000$ and 1:40,000 reacted strongly with full-length $\mathrm{CP}$ of $37 \mathrm{kDa}$ protein and a $28 \mathrm{kDa}$ truncated form of $\mathrm{CP}$ (Fig. 1B, lane 1). Antiserum at both dilutions reacted with a protein of $24 \mathrm{kDa}$ from total proteins of all the samples (Fig. 1B), suggesting that either anti-TriMV antibodies (primary) or goat antirabbit IgG-HRP conjugate (secondary) reacted with this protein.
The specificity and titer of antibodies produced against rCP in two rabbits, four bleeds per rabbit, were further evaluated by DAC-ELISA. Similar results were obtained from both rabbits and representative results from one rabbit are presented in Fig. 2. Crude sap at 1:20 dilution from TriMV-infected wheat leaves was used as a positive control, and WSMV-infected and healthy extracts and buffer were used as negative controls. Antibodies from the 1 st and 2nd bleeds reacted specifically with TriMV-infected sap with average $\mathrm{OD}_{405}$ values of $3.68,2.29$ and 1.54 with $1: 5000,1: 10,000$ and 1:20,000 dilutions of antiserum, respectively, at $30 \mathrm{~min}$ following the addition of substrate (Fig. 2A, B). Antibodies from the 3rd and 4th bleeds at a 1:5000 dilution also reacted strongly with TriMVinfected sap, but with slightly lower $\mathrm{OD}_{405}$ values than the first two bleeds (Fig. 2C, D). Antibodies from all four bleeds reacted strongly with TriMV-infected sap with 11 -16-fold higher $\mathrm{OD}_{405}$ values compared to corresponding dilutions of negative controls (Fig. 2). These results demonstrated that antibodies produced against rCP were specific to TriMV, and did not cross react with sap from WSMVinfected or healthy plants.

\subsection{Antibodies produced against $r C P$ positively reacted with native virions in DAS-ELISA}

Evaluation of antibodies produced against rCP by DAC-ELISA indicated that the 1st and 2nd bleeds contained the highest titers of TriMV-specific antibodies. Hence, antiserum from the 1 st bleed was selected to examine whether antibodies produced against rCP would react with native virions in crude sap in DAS-ELISA. Rabbit anti-TriMV IgG was purified by passing crude antiserum through an affinity chromatography column of a protein A antibody purification kit. The final anti-TriMV IgG concentration was adjusted to $1 \mathrm{mg} / \mathrm{ml}$ and used for further evaluation and conjugation with ALP. In DAC-ELISA, rabbit anti-TriMV IgG at 1:1000, 1:2000, and 1:5000 dilutions reacted strongly with 1:30 diluted crude sap from TriMVinfected plants with $\mathrm{OD}_{405}$ values of 3.07-3.94 at $1 \mathrm{~h}$ following the addition of substrate, but not with WSMV-infected or healthy wheat extracts (Fig. 3A). These results suggest that anti-TriMV IgG reacted specifically with TriMV in crude sap (Fig. 3A).

We next examined whether anti-TriMV IgG-ALP conjugate would react with native virions in DAS-ELISA by using a 1:1000 dilution of anti-TriMV IgG and different dilutions of anti-TriMV IgG-ALP conjugate. Anti-TriMV IgG-ALP conjugate at 1:500, $1: 1000,1: 2500$, and 1:5000 dilutions reacted with TriMV in crude sap with $\mathrm{OD}_{405}$ values of $3.37,2.12,1.09$, and 0.58 , respectively, at $90 \mathrm{~min}$ following the addition of substrate (Fig. 3B). Anti-TriMV IgG-ALP conjugate reacted much more weakly with WSMV-infected or healthy sap with $\mathrm{OD}_{405}$ values of only $0.12-0.20$ (Fig. 3B). These data demonstrated that recombinant antibodies produced against $\mathrm{CP}$ expressed in bacteria reacted strongly with native virions in crude sap from TriMV-infected leaves.

\subsection{Detection limit of antibodies produced against $r C P$ in $D A C$ - and DAS-ELISA}

The detection limit of antibodies produced against rCP was examined using different dilutions of crude sap in DAC- and DAS-ELISA (Fig. 4). Crude antiserum and goat anti-rabbit IgG-ALP conjugate were used at 1:10,000 and 1:2000 dilutions, respectively, for DAC-ELISA. Rabbit anti-TriMV IgG and anti-TriMV IgG-ALP conjugate were used at 1:1000 and 1:500 dilutions, respectively, for DAS-ELISA. Two- and three-fold serial dilutions of crude sap from TriMV- and WSMV-infected and healthy leaves were used for DASand DAC-ELISA, respectively. DAC-ELISA detected TriMV in crude sap up to a $1: 1620$ dilution with more than $3.0 \mathrm{OD}_{405}$ values, and detected TriMV in 1:4860 diluted crude sap with $1.74 \mathrm{OD}_{405}$ (Fig. 4A). DAS-ELISA also detected TriMV strongly in crude sap up 

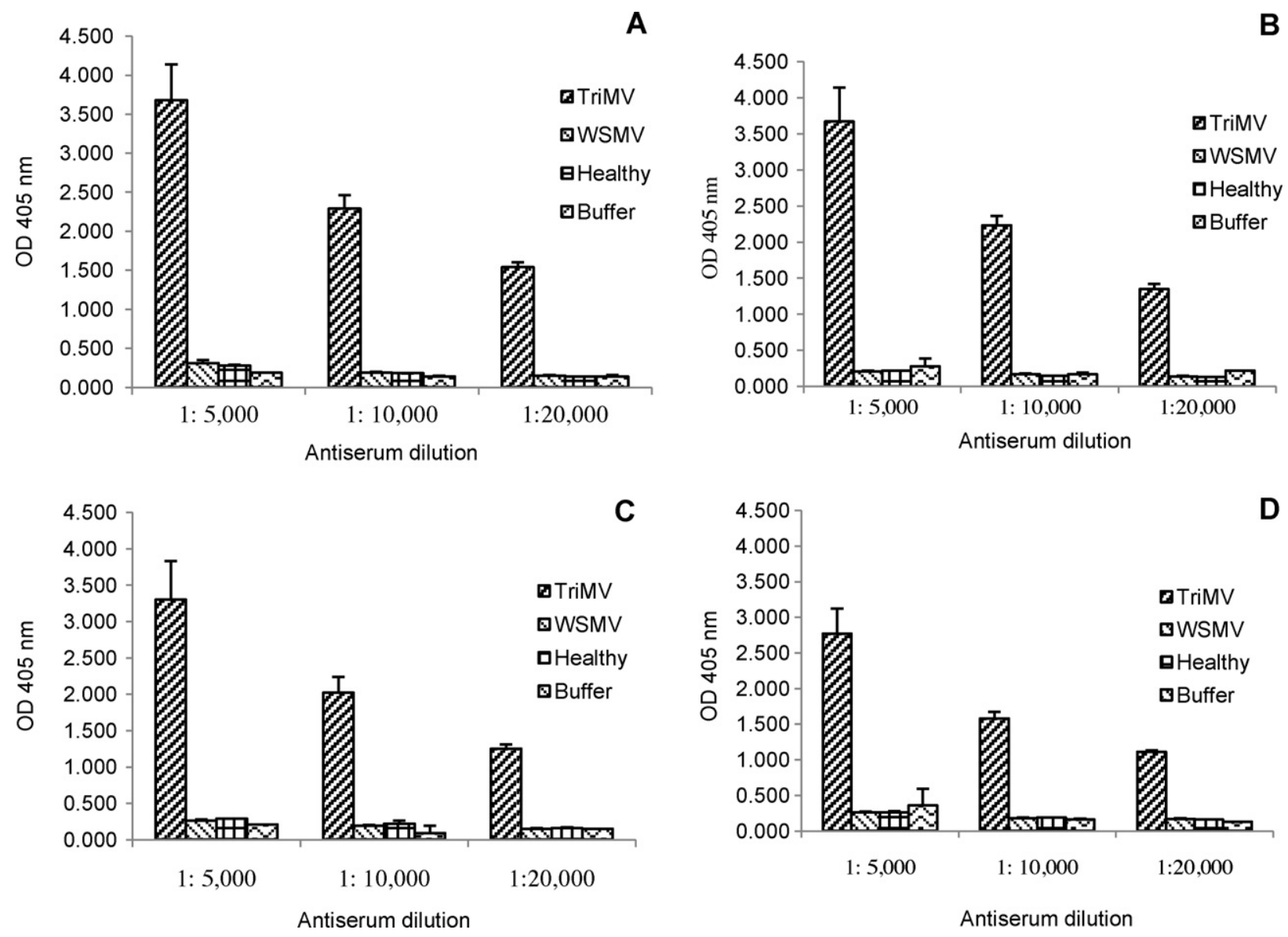

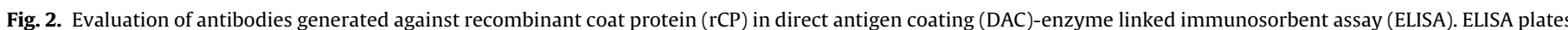

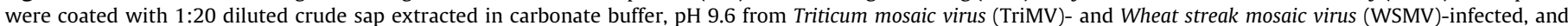

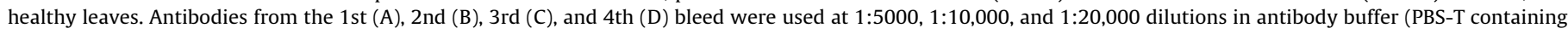

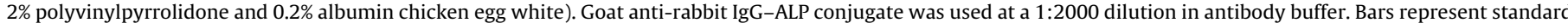
deviations of triplicate wells per sample.

to $1: 80$ dilution with $3.00-3.40 \mathrm{OD}_{405}$ values (Fig. $4 \mathrm{~B}$ ), and detected TriMV in $1: 640,1: 1280$, and $1: 2560$ dilutions of crude sap with 1.15 , 0.813 and $0.625 \mathrm{OD}_{405}$ values (Fig. $4 \mathrm{~B}$ ), which are 3 to 5-fold more than WSMV or healthy OD values. In both DAC- and DAS-ELISA, antibodies reacted very weakly with extracts from WSMV-infected and healthy leaves and buffer, with $\mathrm{OD}_{405}$ values of only $0.11-0.24$ (Fig. 4). These data suggested that antibodies against rCP sensitively detected TriMV in crude sap and that DAC-ELISA was slightly more sensitive than DAS-ELISA.

\subsection{Detection of TriMV in field collected samples}

The applicability of antibodies produced against rCP was examined by testing representative TriMV isolates collected from different regions of the Great Plains using both DAC- and DAS-ELISA (Fig. 5). Crude sap of TriMV isolates was used as antigen at a 1:20 dilution; crude antiserum, rabbit anti-TriMV IgG, and anti-TriMV IgG-ALP conjugate were used at 1:10,000, 1:1000, and 1:500 dilutions, respectively. Both forms of ELISAs, using antibodies raised against rCP, gave strong positive reactions with all TriMV field isolates with $\mathrm{OD}_{405}$ values ranging between 3.10 and 3.68 (Fig. 5), suggesting that antibodies produced against rCP can be used for broad application of TriMV diagnosis in the Great Plains region or elsewhere.

\section{Discussion}

TriMV is an emerging pathogen on wheat in the Great Plains region with symptoms similar to those of WSMV, warranting reliable and sensitive diagnostic methods. The efficient diagnostic methods are required for effective disease management and also for screening of germplasm in wheat breeding programs. In this study, polyclonal antibodies were produced against TriMV CP expressed in bacteria, and these antibodies reacted positively with denatured virions in Western immuno-blot and DAC-ELISA, and also with native virions in DAS-ELISA. Conventionally, purified virions have been used as immunogens to produce antibodies for serologybased detection methods (Van Regenmortel, 1982). Since there is no universal purification method that can be used for all viruses, an extensive standardization is needed to optimize purification methods for each virus. A majority of plant viruses, including potyvirid species accumulate at relatively low concentrations in their respective hosts. As a result, a large amount of infected tissue is needed to purify virions that are sufficiently free from host contaminants to produce virus-specific antibodies. In addition, purification of plant viruses involve expensive high-speed and ultracentrifuges and skilled researchers. These problems can be circumvented by expressing viral proteins in $E$. coli, and these proteins can be used to produce polyclonal antibodies. Antibodies have been produced for several plant viruses against viral CPs expressed in bacteria, and these antibodies successfully reacted with denatured proteins 


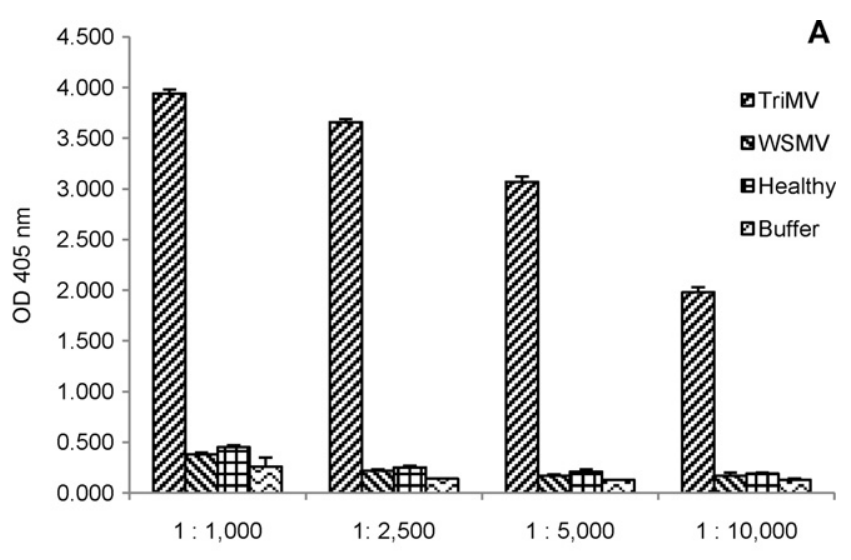

Anti-TriMV IgG dilution

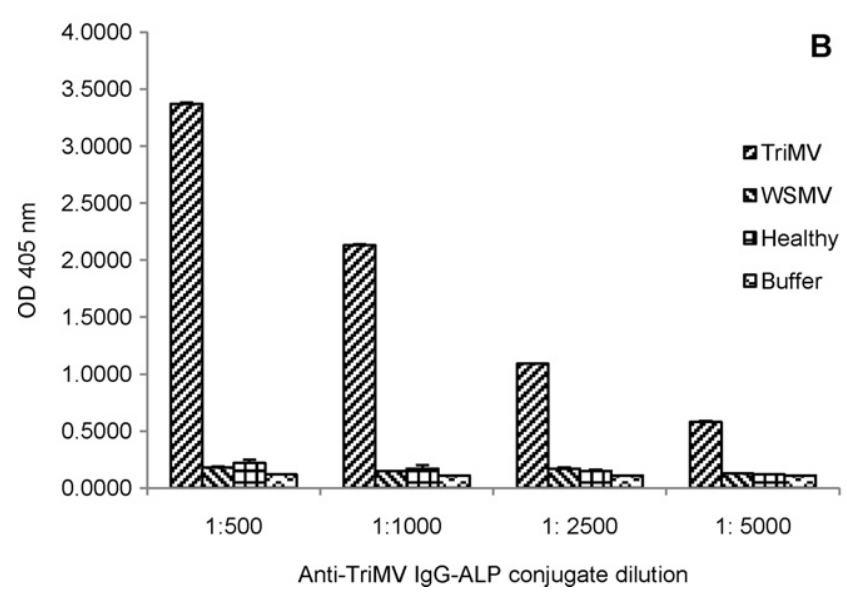

Fig. 3. Antibodies produced against recombinant coat protein ( $\mathrm{rCP})$ reacted with native Triticum mosaic virus (TriMV) virions in double antibody sandwich (DAS)enzyme linked immunosorbent assay (ELISA). (A) Evaluation of Rabbit anti-TriMV IgG purified from antiserum generated against $\mathrm{rCP}$ in direct antigen coating (DAC)ELISA. ELISA plates were coated with 1:30 diluted crude sap in $0.05 \mathrm{M}$ carbonate buffer, pH. 9.6. Anti-TriMV IgG was used at 1:1000, 1:2500, 1:5000, or 1:10,000 dilution. Goat anti-rabbit IgG-ALP conjugate was used at a 1:2000 dilution. ELISA plates were read in a plate reader $90 \mathrm{~min}$ after addition of substrate. (B) Evaluation of antiTriMV IgG-ALP conjugate in DAS-ELISA. ELISA plates were coated with anti-TriMV IgG at a 1:1000 dilution in $0.05 \mathrm{M}$ carbonate buffer, $\mathrm{pH} 9.6$, followed by crude sap at a 1:30 dilution from TriMV- and Wheat streak mosaic virus (WSMV)-infected and healthy leaves. Anti-TriMV IgG-ALP conjugate was used at 1:500, 1:1000, 1:2500, or 1:5000 dilution. ELISA plates were read in a plate reader at $90 \mathrm{~min}$ following the addition of substrate. Bars represent standard deviations of triplicate wells per sample.

in DAC-ELISA and Western blot, but not with native virions in DAS-ELISA (e.g. Abou-Jawdah et al., 2004; Durrin et al., 2010; GulatiSakhuja et al., 2009; Khatabi et al., 2012).

Even though antibodies produced against rCP reacted specifically and sensitively with TriMV-infected crude sap in ELISA, they also reacted weakly in Western blots with a $24 \mathrm{kDa}$ protein present in extracts obtained from healthy plants. It is not clear how antibodies raised against a protein expressed in bacteria reacted positively with a plant protein. However, two different dilutions of TriMV antibodies, 1:20,000 and 1:40,000, similarly reacted with $24 \mathrm{kDa}$ healthy protein in Western immuno-blot, and in ELISA, these antibodies reacted equally with extracts from healthy plants and buffer, suggesting that the $24 \mathrm{kDa}$ protein might have reacted with the secondary antibody in Western immuno-blots, but not with TriMV antibodies.

When compared to antibodies produced against TriMV virions (Seifers et al., 2008), antibodies produced against rCP strongly reacted with TriMV in crude extracts with $\mathrm{OD}_{405}$ values of 3.0-3.8.

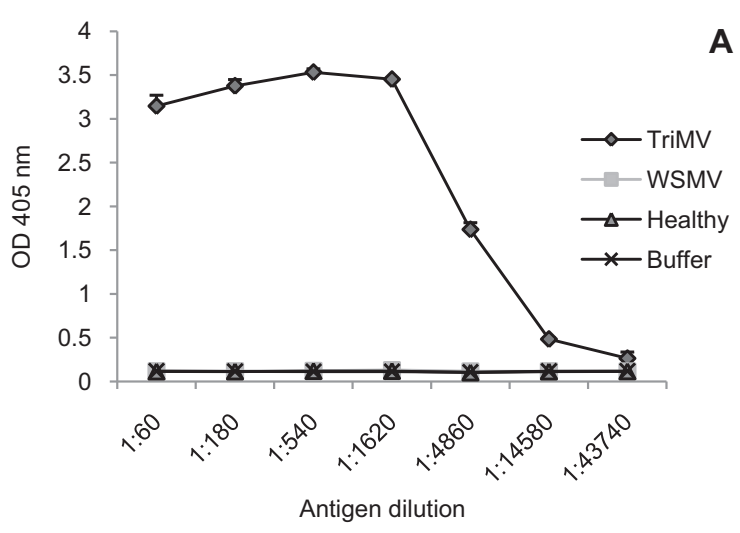

A

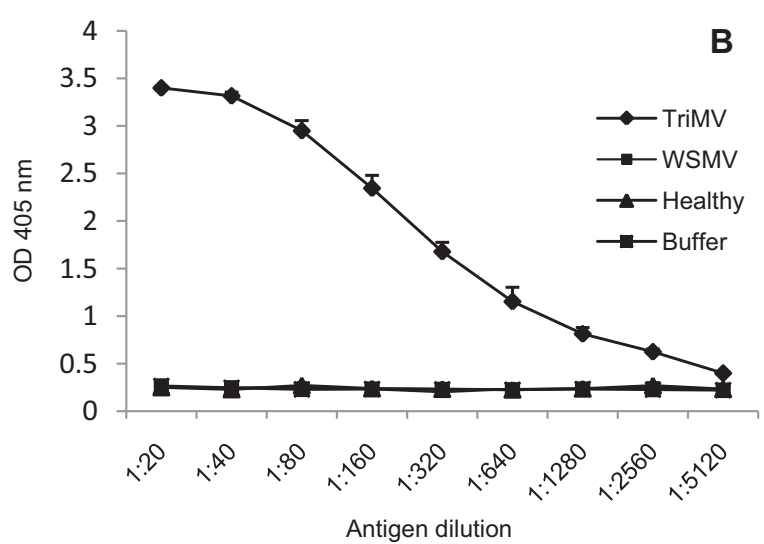

Fig. 4. Comparison of sensitivities of direct antigen coating (DAC)- and double antibody sandwich (DAS)-ELISA using antibodies generated against recombinant coat protein ( $\mathrm{rCP}$ ) of Triticum mosaic virus (TriMV). (A) Detection of TriMV in a three-fold serially diluted crude sap by DAC-ELISA. ELISA plates were coated with different dilutions of crude sap from wheat leaves infected with TriMV and Wheat streak mosaic virus (WSMV) and healthy leaves in $0.05 \mathrm{M}$ carbonate buffer, $\mathrm{pH}$ 9.6. TriMV antiserum and goat anti-rabbit IgG-ALP conjugate were used at 1:10,000 and 1:2000 dilutions in antibody buffer (PBS-T containing $2 \%$ polyvinylpyrrolidone and $0.2 \%$ albumin chicken egg white), respectively. ELISA plates were read in a plate reader 60 min after the addition of substrate. (B) Detection of TriMV in a 2-fold serially diluted crude sap by DAS-ELISA. Anti-TriMV IgG and anti-TriMV IgG-ALP conjugate were used at 1:1000 and 1:500 dilutions in carbonate buffer and antibody buffer, respectively. ELISA plates were read in a plate reader $90 \mathrm{~min}$ following the addition of substrate. Bars represent standard deviations of triplicate wells per sample.

These OD values are 11 to 16 -fold higher compared to those of WSMV-infected or healthy extracts. In contrast to a 1:4000 working dilution of antibodies produced against native virions (Seifers et al., $2008,2010)$, rCP antibodies reacted up to a $1: 20,000$ dilution with $\mathrm{OD}_{405}$ values of more than 3.00. Furthermore, antibodies produced against rCP did not react with extracts from healthy plants and plants infected with WSMV in ELISA, suggesting that these antibodies have high-specific activity. These results demonstrated further that antibodies produced against CP expressed in bacteria can be used for sensitive and specific detection of TriMV.

Antibodies developed against proteins expressed in bacteria may not always be functional for trapping native virions in DASELISA (Nickel et al., 2004). However, TriMV antibodies produced against $\mathrm{rCP}$ readily detected native virions in DAS-ELISA. The possible reasons for positive reaction of antibodies produced against recombinant $\mathrm{rCP}$ with native virions are: the $\mathrm{rCP}$ was purified as a soluble native form and anti-TriMV IgG was purified from crude antiserum using a protein A antibody affinity chromatography. Anti-TriMV IgG purified by ammonium sulfate precipitation also reacted with native virions in DAS-ELISA, but gave relatively low OD values compared to affinity column purified IgG (data not shown). When compared to detection limits of both forms of ELISAs, the 


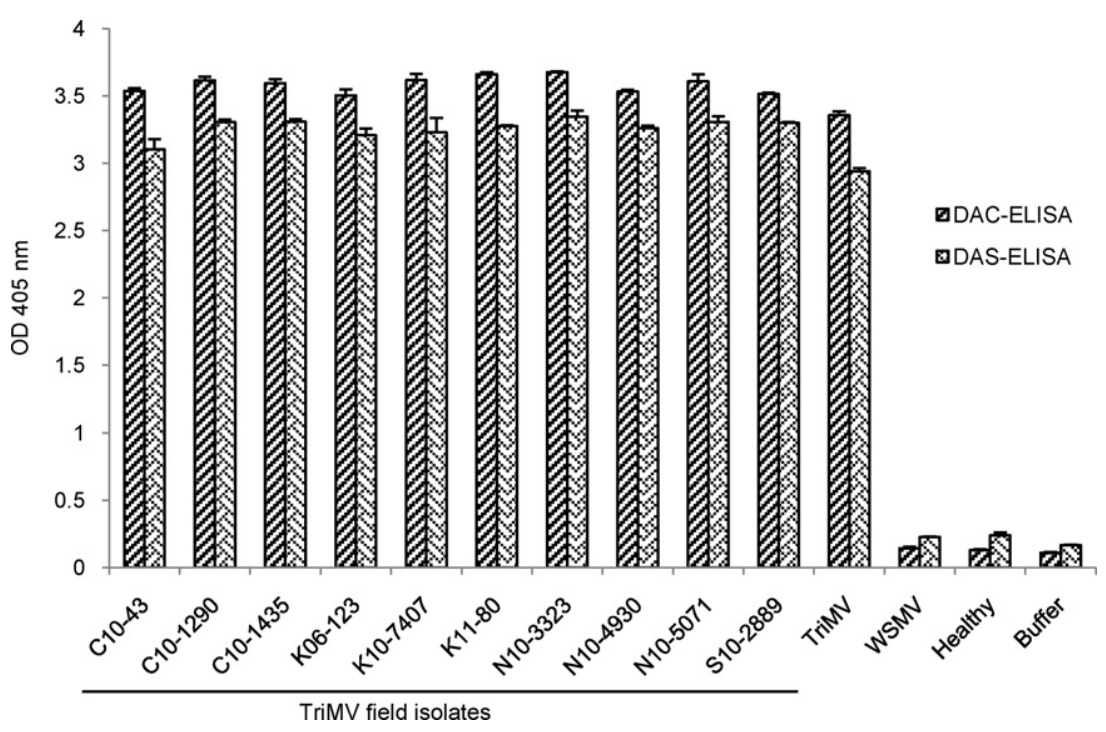

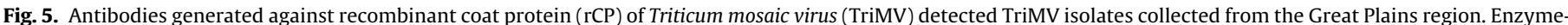

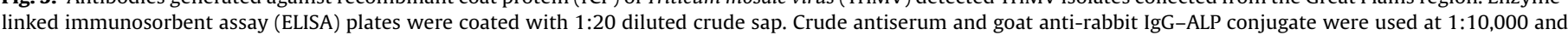

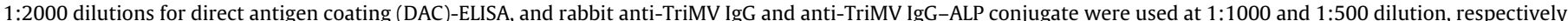

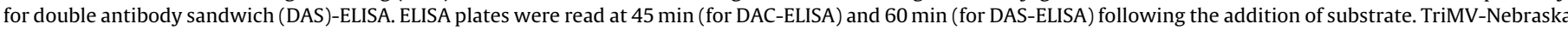

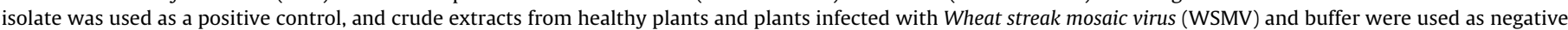
controls. Bars represent standard deviations of triplicate wells per sample. See Table 1 for information concerning each of the isolates of TriMV.

DAC-ELISA had slightly higher sensitivity in detecting TriMV in crude sap compared to DAS-ELISA. This differential detection of TriMV by both forms of ELISAs could be due to lower specific activities of anti-TriMV IgG and anti-TriMV IgG-ALP conjugate used in DAS-ELISA compared to crude antiserum and goat anti-rabbit IgG-ALP conjugate in DAC-ELISA. However, positive reaction of recombinant antibodies with native virions in DAS-ELISA is a step forward in commercialization of diagnostic kits using viral coat proteins expressed in bacteria for several plant viruses.

One characteristic of high-throughput diagnostic methods is the ability to detect virus isolates from different geographical regions. Antibodies produced against rCP readily detected TriMV isolates collected from different states in the Great Plains region, further demonstrating potentially wide application of these antibodies for use in high-throughput diagnostics. Although virus isolates collected from the field were not sequenced, Fuentes-Bueno et al. (2011) and French et al. (2012) reported that the coat protein of TriMV isolates from the Great Plains region is highly conserved with no more than five amino acid differences. The availability of $\mathrm{rCP}$ antibodies with specific and strong reaction against TriMV could provide a robust diagnostic method for this emerging viral disease in the Great Plains region.

\section{Acknowledgements}

This research was supported in part by a research grant from the Nebraska Wheat Board. We thank Craig J. Aldrich and Jonathan Horrell for their technical assistance. Mention of trade names or commercial products in this publication is solely for the purpose of providing specific information and does not imply recommendation or endorsement by the U.S. Department of Agriculture.

\section{References}

Abou-Jawdah, Y., Sobh, H., Cordahi, N., Kawtharani, H., Nemer, G., Maxwell, D.P., Nakhla, M.K., 2004. Immunodiagnosis of prune dwarf virus using antiserum produced to its recombinant coat protein. J. Virol. Methods 121, 31-38.

Adams, M.J., Zerbini, F.M., French, R., Rabenstein, F., Stenger, D.C., Valkonen, J.P.T. 2011. Potyviridae. In: Adams, Andrew M.Q., Wada, Michael J., Carstens, Eric B., Lefkowitz, Elliot J. (Eds.), Virus Taxonomy. Elsevier, Oxford, pp. 1069-1090.
Byamukama, E., Tatineni, S., Hein, G.L., Graybosch, R.A., Baenziger, P.S., French, R. Wegulo, S.N., 2012. Effects of single and double infections of winter wheat by Triticum mosaic virus and Wheat streak mosaic virus on yield determinants. Plant Dis. 96, 859-864.

Byamukama, E., Seifers, S.D., Hein, G.L., De Wolf, E., Tissert, N., Langham, M. Osborne, L.E., Timmerman, A.D., Wegulo, S.N., 2013. Occurrence and distribution of Triticum mosaic virus in the Central Great Plains. Plant Dis. 97, 21-29.

Burrows, M., Franc, G., Rush, C., Blunt, T., Ito, D., Kinzer, K., Olson, J., O'Mara, J., Price, J., Tande, C., Ziems, A., Stack, J., 2009. Occurrence of viruses in wheat in the Great Plains region 2008. Plant Health Prog. http://dx.doi.org/10.1094/PHP-2009-0706-01-RS

Choi, I.R., French, R., Hein, G.L., Stenger, D.C., 1999. Fully biologically active in vitro transcripts of the eriophyid mite-transmitted wheat streak mosaic tritimovirus. Phytopathology 89, 1182-1185.

Clark, M.F., Adams, A.N., 1977. Characteristics of the microplate method of enzymelinked immunosorbent assay for the detection of plant viruses. J. Gen. Virol. 34 475-483.

Dekker, E.L., Dore, I., Porta, C., Van Regenmortel, M.H.V., 1987. Conformational specificity of monoclonal-antibodies used in the diagnosis of Tomato mosaic virus Arch. Virol. 94, 191-203.

Durrin, J.S., Nikolaeva, O.V., Strausbaugh, C.A., Karasev, A.V., 2010. Immunodetection of two curtoviruses infecting sugar beet. Plant Dis. 94, 972-976.

Fellers, J.P., Seifers, D., Ryba-White, M., Martin, T.J., 2009. The complete genome sequence of Triticum mosaic virus a new wheat-infecting virus of the High Plains. Arch. Virol. 154, 1511-1515.

French, R., Seifers, D., Wegulo, S.N., Tatineni, S., 2012. Triticum mosaic virus: genetic evidence for recent population expansion and balancing selection. Phytopathology 102, S4.42.

Fuchs, M., Gonsalves, D., 2007. Safety of virus-resistant transgenic plants two decades after their introduction: lessons from realistic field risk assessment studies. Annu. Rev. Phytopathol. 45, 173-202.

Fuentes-Bueno, I., Prince, J.A., Rush, C.M., Seifers, D.L., Fellers, J.P., 2011. Triticum mosaic virus isolates in the South Great Plains. Plant Dis. 95, 1516-1519.

Gulati-Sakhuja, A., Sears, J.L., Nunez, A., Liu, H.-Y., 2009. Production of polyclonal antibodies against Pelargonium zonate spot virus coat protein expressed in Escherichia coli and application for immunodiagnosis. J. Virol. Methods 160 29-37.

Harlow, E., Lane, D., 1988. Antibodies: A laboratory Manual. Cold Spring Harbor Laboratory Press, Cold Spring Harbor, New York, p. 349, (Chapter 9).

Hobbs, H.A., Reddy, D.V.R., Rajeshwari, R., Reddy, A.S., 1987. Use of direct antigen coating and protein A coating ELISA procedures for three peanut viruses. Plant Dis. 71, 747-749.

Hull, R., 2002. Matthews' Plant Virology. Academic Press, New York.

Jones, R.A.C., 2006. Control of plant virus diseases. Adv. Virus Res. 67, 205-244.

Khatabi, B., He, B., Hajimorad, M.R., 2012. Diagnostic potential of polyclonal antibodies against bacterially expressed recombinant coat protein of Alfalfa mosaic virus. Plant Dis. 96, 1352-1357.

Nickel, O., Tragón, M.L.P.N., Fajardo, T.V.M., Machado, M.A., Trivilin, A.P., 2004. Polyclonal antibodies to the coat protein of Apple stem grooving virus expressed in Escherichia coli: production and use in immunodiagnosis. Fitopatol. Bras. 29, 558-562. 
Prins, M., Laimer, M., Noris, E., Schubert, J., Wassenegger, M., Tepfer, M., 2008. Strategies for antriviral resistance in transgenic plants. Mol. Plant Pathol. 9, 73-83.

Sambrook, J., Russell, D., 2001. Molecular Cloning: A Laboratory manual, 3rd ed. Cold Spring Harbor Laboratory Press (3 volume set), p. 2344.

Sander, E., Dietzgen, R.G., 1984. Monoclonal-antibodies against plant-viruses. Adv. Virus Res. 29, 131-168.

Seifers, D.L., Martin, T.J., Harvey, T.L., Fellers, J.P., Stack, J.P., Ryba-White, M., Haber, S., Krokhin, O., Spicer, V., Lovat, N., Yamchuk, A., Standing, K.G., 2008. Triticum mosaic virus: A new virus isolated from wheat in Kansas. Plant Dis. 92, 808-817.

Seifers, D.L., Martin, T.J., Harvey, T.L., Fellers, J.P., Michaud, J.P., 2009. Identification of the wheat curl mite as the vector of Triticum mosaic virus. Plant Dis. 93, 25-29.

Seifers, D.L., Martin, T.J., Fellers, J.P., 2010. An experimental host range for Triticum mosaic virus. Plant Dis. 94, 1125-1131.

Tatineni, S., Ziems, A.D., Wegulo, S.N., French, R., 2009. Triticum mosaic virus: a distinct member of the family Potyviridae with an unusually long leader sequence. Phytopathology 99, 943-950.
Tatineni, S., Graybosch, R.A., Hein, G.L., Wegulo, S.N., French, R., 2010. Wheat cultivar-specific disease synergism and alteration of virus accumulation during co-infection with Wheat streak mosaic virus and Triticum mosaic virus. Phytopathology 100, 230-238.

Tatineni, S., McMechan, J.A., Hein, G.L., French, R., 2011. Efficient and stable expression of GFP through Wheat streak mosaic virus-based vectors in cereal hosts using a range of cleavage sites: formation of dense fluorescent aggregates for sensitive virus tracking. Virology 410, 268-281.

Tatineni, S., Qu, F., Li, R., Morris, T.J., French, R., 2012. Triticum mosaic poacevirus enlists P1 rather than HC-Pro to suppress RNA silencing-mediated host defense. Virology 433, 104-115.

Van Regenmortel, M.H.V., 1982. Serology and Immunochemistry of Plant Viruses. Academic Press Inc, New York. 